\title{
Efeitos jurídicos da multiparentalidade
}

\author{
Legal effects of multiparentality
}

\author{
Anderson Schreiber \\ Paulo Franco Lustosa*
}

\section{Resumo}

O presente artigo examina os efeitos jurídicos da multiparentalidade nos diferentes campos do Direito, especialmente no Direito de Família e no Direito das Sucessões. Embora, em setembro de 2016, o Supremo Tribunal Federal brasileiro tenha reconhecido a possibilidade de multiparentalidade, diversas questões jurídicas permanecem em aberto, como o modo de divisão da herança caso o filho faleça anteriormente aos seus múltiplos pais, ou, ainda, como se aplicam os direitos de guarda e visitação em casos de multiparentalidade. Essas e outras questões são abordadas pelo presente artigo, que propõe soluções baseadas na doutrina e na jurisprudência, demonstrando que a multiparentalidade pode não ser tão problemática quanto aparenta à primeira vista.

Palavras-chave: Multiparentalidade. Parentalidade. Direito de família.

\section{Abstract}

The present article examines the legal effects of multiparentality, in the differentes fields of Law, specially in Family Law and Inheritance Law. Although on September, 2016, the Brazilian Supreme Federal Court has recognized the possibility of multiparentality, several legal issues remain unclear, regarding, for example, the division of inheritance in case a son deceases before his

* Professor dos cursos de Pós-Graduação do CEPED-UERJ e FGV. Professor de Direito Civil da UERJ. Procurador do Estado do Rio de Janeiro. Doutor em Direito Privado Comparado pela Università degli studi del Molise (Italia). Mestre em Direito Civil pela UERJ. Rio de Janeiro - RJ Brasil. E-mail: schreiber@sdls.com.br

** Professor Substituto de Direito Civil e Direito Internacional Privado da Faculdade Nacional de Direito da UFRJ. Mestre em Direito Civil pela Universidade do Estado do Rio de Janeiro (UERJ). Pós-graduado em Direito Civil-Constitucional pela UERJ. Advogado do Banco Nacional de Desenvolvimento Econômico e Social - BNDES. Rio de Janeiro - RJ - Brasil. E-mail: paulolustosa@gmail.com 
multiparents or how does custody and visitation rights apply to multiparents. These and other issues are addressed by the present article, which indicates solutions based on doctrine and jurisprudence, prooving that multiparentality may be not so problematic as it might appear at first glance.

Keywords: Multiparentality. Parentality. Family law.

\section{Introdução}

Ao julgar o Recurso Extraordinário n 898.060 , em 22 de setembro de 2016, o Plenário do Supremo Tribunal Federal fixou tese de repercussão geral que assume caráter histórico e, pode-se mesmo dizer, revolucionário no direito brasileiro. Nossa Suprema Corte afirmou que "a paternidade socioafetiva, declarada ou não em registro público, não impede o reconhecimento do vínculo de filiação concomitante baseado na origem biológica, com os efeitos jurídicos próprios" (Repercussão Geral 622). Com isso, além de solucionar controvérsias ainda existentes em relação à parentalidade socioafetiva, abriu as portas do sistema jurídico pátrio para o fenômeno da multiparentalidade, também chamado de pluriparentalidade.

A decisão é fruto de longa transformação operada no Direito de Família nas últimas décadas, em especial após a promulgação da Constituição de 1988, que consolidou uma nova concepção jurídica do fenômeno familiar: plural, igualitário, democrático e funcionalizado à promoção da personalidade de seus membros, na medida em que é a pessoa humana o elemento finalístico da proteção estatal (TEPEDINO, 2008, p. 394). Nessa "redescoberta" da família, a antiga concepção jurídica do instituto, exclusivamente calcada no matrimônio, foi progressivamente substituída pelas chamadas "entidades familiares", que incluem, em listagem aberta, as famílias monoparentais, as uniões homoafetivas, a família fundada no casamento, as uniões estáveis, as famílias recompostas, as famílias anaparentais, e assim por diante (LÔBO, 2002), podendo-se acrescentar agora o exemplo das famílias multiparentais. 
Nesse cenário, a decisão do STF revelou-se corajosa e ousada, exprimindo clara ruptura com o dogma antiquíssimo segundo o qual cada pessoa tem apenas um pai e uma mãe. Em um campo tão delicado como o da família, cercado de "pré-conceitos" de origem religiosa, social e moral (por vezes, moralista), o STF adotou um posicionamento claro e objetivo, em sentido diametralmente oposto ao modelo da dualidade parental, consolidado na tradição civilista e construído à luz da chamada "verdade" biológica.

Com isso, o fenômeno da multiparentalidade - que já era uma realidade, não apenas no plano fático-social, mas também na experiência de diversos tribunais brasileiros - deixou de ser, definitivamente, um fato ignorado e marginalizado pelo Direito. A partir do leading case do STF, a tendência é que surjam, cada vez mais, decisões judiciais declarando a existência de múltiplos laços parentais aptos a gerar os efeitos jurídicos decorrentes do parentesco. Trata-se de notório avanço na desejada aproximação entre o Direito e a realidade social, permitindo que se concretize relevante comando da Constituição, que, ao consagrar a plena igualdade de direitos entre os filhos (art. 227, $\S 6^{\circ}$ ), veda qualquer relação de hierarquia, apriorística ou não, que se pretenda estabelecer entre os critérios de fixação da parentalidade, quer se trate de parentalidade biológica, socioafetiva ou jurídica (presumida). Tal assertiva é reforçada pelo art. 20 do Estatuto da Criança e do Adolescente e pelo art. 1.596 do Código Civil, que possuem redação idêntica àquela do dispositivo constitucional, desautorizando qualquer restrição de direitos ou deveres em razão da qualificação do parentesco como natural ou civil. Daí decorre a admissão da formação de múltiplos vínculos de parentalidade, de forma originária ou superveniente, sem que seja necessária a substituição de um vínculo pelo outro, como bem decidiu nossa Suprema Corte.

Cumpre notar, todavia, que o admirável precedente não chegou a jogar uma pá de cal sobre todas as polêmicas em torno da multiparentalidade. O próprio julgamento e a análise da tese aprovada, ao final, não se mostraram muito coesos, com propostas antagônicas e algumas reviravoltas, a revelar que a visão do tema entre os Ministros 
não é necessariamente unívoca (SCHREIBER, 2016). Há, ademais, uma forte resistência cultural à superação do paradigma da sacralidade da família nuclear - constituída pelo pai, pela mãe e pelos filhos -, pululando controvérsias em torno dos requisitos necessários para a constituição de novos vínculos de parentalidade sem exclusão dos laços então existentes, notadamente naquelas situações em que o pedido de reconhecimento do vínculo parental surge no âmbito de ação proposta com vistas à aplicação de efeitos puramente patrimoniais, em especial o reconhecimento de direito à herança após a abertura da sucessão, como ocorreu no célebre caso Hans Stern ${ }^{1}$ (BEZERRA, 2012).

Embora cada vez mais presente na pauta contemporânea do Direito de Família, a ideia de multiparentalidade ainda desperta natural perplexidade, especialmente em virtude da forte mentalidade tradicional, que elege - por vezes até inconscientemente - a família nuclear como modelo ideal de arranjo a ser adotado e promovido na vida em sociedade. Com isso, o senso comum tende a imaginar que a consagração de múltiplos laços de parentesco traria um sem-número de problemas práticos, gerando mais insegurança jurídica que justiça. Daí a oportunidade do presente estudo que, examinando os efeitos decorrentes da admissão de múltiplos laços de parentalidade, pode contribuir para a superação de preconceitos e desconstrução de mitos, permitindo, com isso, conclusões técnicas seguras, que facilitem o exame criterioso das consequências da multiparentalidade no direito brasileiro.

\footnotetext{
Após exame de DNA, dois irmãos com mais de 50 anos descobriram ser filhos de Hans Stern, dono de uma famosa joalheria, morto em 2007, deixando uma herança multimilionária. Buscando o direito à herança, propuseram ação de investigação de paternidade, que tramita em segredo de justiça na $2^{a}$ Vara de Família do Tribunal de Justiça do Rio de Janeiro. Em sua defesa, os outros filhos de Hans Stern alegaram que os autores não têm direito à herança, já que por toda a vida tiveram outro homem como pai, que, ao morrer, há 15 anos, deixara inclusive herança para os dois.
} 


\section{Conceitos de multiparentalidade e sua trajetória na jurisprudência brasileira}

A multiparentalidade pode ser conceituada em acepção ampla ou em acepção estrita. A multiparentalidade lato sensu consiste no reconhecimento, pelo ordenamento jurídico, de que uma pessoa tenha mais de um vínculo parental paterno ou mais de um vínculo parental materno. Para a sua configuração, é suficiente que alguém tenha dois pais ou duas mães, o que abarca não apenas os arranjos multiparentais que, por circunstâncias e fundamentos diversos, envolvam duas mães e um pai, dois pais e uma mãe, e assim por diante, mas também os casos de simples biparentalidade homoafetiva, em que a distinção de gênero afigura-se, a rigor, inaplicável. É nessa acepção ampla que o fenômeno costuma ser estudado no Brasil.

Já em acepção restrita, a multiparentalidade pode ser definida como o reconhecimento jurídico de mais de dois vínculos de parentalidade à mesma pessoa. Em outros termos, a expressão estaria reservada às hipóteses em que alguém tenha três ou mais laços parentais, não abrangendo, portanto, a mera dupla paternidade ou dupla maternidade se desacompanhada do terceiro ascendente, que resultaria na configuração de mais de dois vínculos parentais. São casos de multiparentalidade stricto sensu, por exemplo, aqueles em que uma pessoa tem duas mães e um pai, dois pais e uma mãe, três mães, dois pais e duas mães, e assim sucessivamente. Note-se que tal acepção se revela mais adequada ao significado das expressões multiparentalidade e pluriparentalidade, cujos prefixos exprimem noção de muitos, em contraposição à biparentalidade.

Percorrer o panorama da jurisprudência brasileira sobre a matéria ajuda a compreender o conceito de multiparentalidade em seus aspectos mais polêmicos. Os primeiros casos de multiparentalidade reconhecidos judicialmente de que se tem notícia no Brasil dizem respeito a hipóteses inseridas na noção alargada da expressão. Tratam-se de casos de 
homoparentalidade ${ }^{2}$, situação bastante difundida na atualidade, que se verifica nas entidades familiares formadas por pessoas do mesmo sexo. Já é possível afirmar que a adoção unilateral (pelo cônjuge ou companheiro homoafetivo) ou conjunta (por cônjuges ou companheiros do mesmo sexo) tornou-se prática amplamente admitida na jurisprudência pátria ${ }^{3}$. Há, ainda no campo da homoafetividade, decisões autorizando a averbação de dupla maternidade ou dupla paternidade no registro de nascimento, prescindindo, portanto, do processo de adoção4.

Por sua vez, as hipóteses que podem ensejar a constituição de mais de dois laços de parentesco (três ou mais ascendentes de primeiro grau) são variadas e não devem ser arroladas de forma exaustiva, tendo em vista a riqueza da realidade dos fatos e a complexidade da sociedade tecnológica. A ocorrência mais corriqueira, sem dúvida, se dá por meio do vínculo de paternidade ou maternidade socioafetiva, quando constituído sem a exclusão dos pais biológicos. ${ }^{5}$ É o que muitas vezes sucede nas famílias reconstituídas, também chamadas famílias-

2 Interessante notar que o Superior Tribunal de Justiça admitiu a adoção conjunta por família homoafetiva em 2010 (REsp 889852/RS, 4ª T., Min. Luis Felipe Salomão, j. em 27/04/2010), ou seja, antes mesmo do julgamento da Ação Direta de Inconstitucionalidade 4277 pelo Supremo Tribunal Federal em 5/5/2011, na qual foi reconhecida a união entre pessoas do mesmo sexo como entidade familiar.

3 Para ilustrar, ainda no âmbito do STJ, mencionem-se o acórdão proferido no REsp 1281093/SP, $3^{a}$ T., Rel. Min. Nancy Andrighi, j. em 18/12/2012, bem como a decisão monocrática proferida pelo Min. César Asfor Rocha nos autos do pedido de homologação de sentença estrangeira de adoção 4.525/US, em 25/06/2010.

4 Vide sentenças proferidas nos autos do processo 0395929-28.2013.8.19.0001, Juíza de Direito Daniela Brandão Ferreira, em 27/11/2013, $1^{\text {a }}$ Vara de Família do TJRJ; processo 001293986.2012.8.26.0100, $2^{\mathrm{a}}$ Vara de Registros Públicos do TJSP, Juiz de Direito Márcio Martins Bonilha Filho, 28/09/2012; entre outros. Merece destaque, ainda, a decisão da Corregedoria do Tribunal de Justiça do Piauí, nos autos do Pedido de Providências 0001313-38.2013.8.18.0139, em 19/12/2013, que orientou "todos os cartórios de registro de pessoas naturais a procederem, atendidos os demais requisitos legais e regulamentares, ao registro das duas mães, nas hipóteses em que, cumulativamente, i) ambas mantiverem união estável; ii) uma delas, comprovadamente, tiver fornecido o óvulo em procedimento de reprodução assistida, e a outra tenha gestado a criança".

5 De acordo com notícia publicada pelo IBDFAM em 17.6.2015, os Estados de Pernambuco, Ceará, Maranhão, Amazonas e Santa Catarina já expediram provimentos regulamentando o procedimento de reconhecimento voluntário da filiação socioafetiva em cartório (www.ibdfam.org. $\mathrm{br} /$ noticias/5663). 
mosaico ou recompostas, quando o padrasto também se torna pai ou a madrasta também se torna mãe, sem prejuízo dos laços biológicos (BARBOZA, 2009).

Há também decisões nas quais ao pai socioafetivo - geralmente pai registral, em casos de "adoção à brasileira" - se vem acrescer o pai biológico ${ }^{6}$. Ao admitir a multiplicidade de vínculos parentais, tais decisões vinham relativizando a polêmica que, há décadas, reinava na academia e nos tribunais, em torno do conflito entre a parentalidade biológica e a socioafetiva, verdadeira "escolha de Sofia" (TARTUCE, 2014). A corrente que vinha se consolidando no Superior Tribunal de Justiça levava em consideração quem tomava a iniciativa para postular, em juízo, a constituição do novo vínculo ou a desconstituição do existente: na ação negatória de parentalidade proposta pelo pai registral ou por seus herdeiros, deveria prevalecer a socioafetividade; ao passo que, na ação de investigação proposta pelo filho, prevaleceria o laço biológico. Entretanto, no início de 2015, a $3^{\text {a }}$ Turma do STJ entendeu, por unanimidade, que o pai registral pode desconstituir a paternidade que não corresponda à verdade biológica em caso de vício do consentimento (erro) por ocasião do registro, mesmo após o convívio duradouro com incontroversa relação de afeto $^{7}$. A confusão que prometia se formar foi em boa hora dirimida pelo STF, com a tese fixada na Repercussão Geral 622 , que conclui claramente não representar a paternidade socioafetiva uma paternidade de segunda categoria, tampouco de categoria superior, diante da paternidade biológica.

Além das hipóteses examinadas, cumpre registrar que as técnicas de reprodução assistida heteróloga também podem ensejar a formação

\footnotetext{
$6 \quad$ Pode ser citada, como exemplo, sentença judicial, de maio de 2014, em que a juíza Carine Labres, da $3^{a}$ Vara Cível de Santana do Livramento (RS), decidiu que um menino de cinco anos teria na certidão de nascimento o nome do pai biológico e do pai que o registrou e convive desde o nascimento. A decisão da juíza leva em consideração o aspecto da multiparentalidade, reconhecendo a verdade biológica e a realidade afetiva, priorizando a melhor resolução para a criança sobre as normas do direito. Processo em segredo de justiça.
}

7 BRASIL. STJ. REsp 1.330.404/RS. Rel. Min. Marco Aurélio Bellizze, j. 5/2/2015, DJe 19/2/2015. 
de múltiplos laços de parentesco, ampliando de forma considerável o universo de eventos capazes de configurar a multiparentalidade. A título de ilustração, pode ser mencionada a hipótese em que o doador do material genético não é anônimo e também pretende constituir vínculo ${ }^{8}$ ou, ainda, situações mais complexa em que uma mãe "doa" o óvulo, outra "empresta" o útero e a terceira se propõe a cuidar da criança. A ciência vem, na mesma direção, dando provas da possibilidade de combinação de material genético de mais de duas pessoas para geração de seres humanos, como ocorreu recentemente no México. ${ }^{9}$ Por fim, não devem ser descartadas outras possibilidades, que eventualmente podem vir a encontrar guarida no ordenamento jurídico, tais como a adoção sem

8 Em 19.5.2016, o juízo da $4^{\text {a }}$ Vara Cível de Santos/SP julgou procedente pedido para registro de multiparentalidade formulado por duas mulheres casadas e o doador do gameta na inseminação artificial. Em sua decisão, o magistrado observou que "o terceiro é o doador do gameta, pessoa conhecida do casal, donde, portanto, não incide o dever de anonimato de que trata a Resolução 2121/15 do CRM. Ademais, pela procuração que fez juntar aos autos, reconheceu voluntariamente a paternidade do nascituro". Invocando o direito constitucional de planejamento familiar, o juiz contrariou a opinião do Ministério Público estadual e considerou que ambas as requerentes, oficialmente casadas, são genitoras do nascituro, além do doador do gameta. Assim, determinou que constasse da Declaração de Nascido Vivo e do assento de nascimento o nome dos três genitores e dos respectivos avós paternos e maternos (processo n $1007915-$ 90.2016.8.26.0562).

9 Em um exemplo recente de como a evolução tecnológica pode ensejar novas hipóteses de multiparentalidade, mencione-se o nascimento, noticiado pela revista New Scientist, do primeiro bebê no mundo a partir de uma técnica de fertilização que usa material genético de três pessoas. Identificado apenas como I.H. por questão de privacidade, o primeiro filho biológico de três pessoas nasceu em 6/4/2016 e tem pais jordianos que receberam tratamento de uma equipe americana no México (www.newscientist.com/article/2107219). A controversa técnica de fertilização in vitro com três genitores, usando o óvulo da mãe, o esperma do pai e o óvulo de uma doadora para gerar um embrião, permite que pais e mães com uma rara mutação genética tenham bebês saudáveis. Uma mulher com DNA mitocondrial defeituoso, que pode passar ao filho diferentes doenças congênitas, tem o núcleo de seu óvulo removido. Este núcleo, carregando informações genéticas como altura, cor dos olhos e cor da pele, é então implantado no óvulo de uma doadora, com DNA mitocondrial saudável. Este óvulo, com informações de ambas as mulheres, é, em seguida, fecundado pelo esperma do pai. O embrião gerado tem $0,1 \%$ de DNA da doadora. Tal procedimento foi aprovado, pelo parlamento britânico, em 3/2/2015, em meio a uma polêmica entre os que defendiam o uso da técnica para fins de evitar a transmissão de doenças hereditárias e aqueles que a acusavam de permitir o "design de bebês", tornando o Reino Unido o primeiro país a legalizar a referida técnica (oglobo.globo.com/sociedade/saude/ fertilizacao-com-tres-genitores-votada-em-meio-polemica-no-reino-unido). 
ruptura com a família biológica ${ }^{10}$ ou a parentalidade socioafetiva (ou mesmo adoção conjunta) em casos de poliamor ${ }^{11}$.

Nesse complexo cenário, adquire relevância, para fins de identificação e análise dos efeitos jurídicos da multiplicidade de vínculos parentais, a distinção conceitual já mencionada entre as acepções ampla e restrita da multiparentalidade. Nos casos em que o número de ascendentes não chega a três (apenas dois pais ou apenas duas mães), revela-se desnecessário tecer maiores considerações sobre as consequências advindas do vínculo multiparental, pois, seja a hipótese de pais de sexo distinto, seja do mesmo sexo, os efeitos jurídicos serão idênticos aos tradicionalmente previstos para a biparentalidade. Com efeito, a plena igualdade entre o homem e a mulher, hoje amplamente reconhecida, e o direito fundamental de livre orientação sexual impõem uma idêntica eficácia jurídica no que se refere ao laço de parentesco estabelecido com os filhos nas entidades familiares heteroafetivas ou homoafetivas. Logo, no que tange aos efeitos jurídicos decorrentes da relação da parentalidade, afigura-se irrelevante saber se a biparentalidade é heterogênea ou homogênea - classificação, de resto, se mostra redutora e artificiosa diante da rica complexidade do fenômeno homoafetivo.

Já a multiparentalidade em sentido estrito, assim entendida aquela que se verifica diante da presença de três ou mais vínculos de

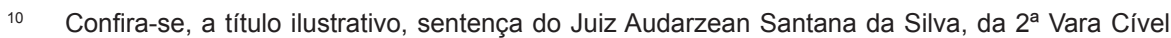
da Comarca de Cacoal, no Estado de Rondônia, que, em janeiro de 20154, admitiu a adoção sem rompimento do vínculo anterior, já que a mãe biológica concordou com o desejo do filho, já esboçado em depoimento, de ter "um registro de nascimento com o nome dos dois pais e das duas mães" (www.ibdfam.org.br/noticias/5234).

11 Merece destaque, nessa direção, a decisão proferida pelo Juízo da $3^{a}$ Vara de Família de Niteroi/RJ, em 6/6/2016, em Ação de Divórcio Consensual cumulada com Declaratória de Multiparentalidade. De acordo com a sentença, os autores da ação (Andréa, Simone e Marcelo) partilharam do desejo do nascimento de Jonas, assim como da responsabilidade por sua criação, de tal forma que a criança reconhece e sempre conviveu com duas mães - Andréa e Simone - e um pai - Marcelo. Julgou-se, assim, procedente o pedido de reconhecimento de filiação socioafetiva, determinando-se a averbação junto ao Registro Civil de Pessoas Naturais, para que, sem prejuízo da filiação já existente, fosse o nome de Andréa acrescido ao registro de nascimento do filho, constando também os respectivos nomes dos avós maternos (Processo $\mathrm{n}^{\circ}$ 0060258-43.2015.8.19.0002). 
parentesco, pode ensejar, aí sim, inúmeras dificuldades interpretativas, sobretudo em questões relacionadas ao Direito das Sucessões e ao Direito de Família, uma vez que o legislador disciplinou tais relações jurídicas à luz do paradigma da biparentalidade. Assim, passa-se a analisar os efeitos jurídicos da multiparentalidade stricto sensu, isto é, naquelas relações em que se reconhecem mais de dois vínculos parentais a uma pessoa. Antes, porém, convém recordar brevemente quais são os efeitos jurídicos que decorrem do vínculo de filiação.

\section{Os efeitos jurídicos da parentalidade}

A parentalidade, seja "natural" (rectius: biológica), seja proveniente de adoção, socioafetividade ou reprodução assistida heteróloga, produz efeitos jurídicos: (i) existenciais, como a criação de impedimentos matrimoniais e o direito à guarda e visitação; e (ii) patrimoniais, como os direitos e deveres a alimentos e à sucessão (BARBOZA, 2009, p. 33). Note-se que, além dos efeitos no campo do Direito de Família e no Direito de Sucessões, o vínculo de parentalidade repercute também no Direito das Obrigações (por exemplo, na responsabilidade civil dos pais por atos dos filhos menores e no regime aplicável aos contratos de doação ou compra e venda entre pais e filhos), bem como em diversos outros ramos jurídicos, tais como o Direito Administrativo (vedação ao nepotismo), Eleitoral (regras de inelegibilidade), Processual (regras de suspeição do juiz e de produção de prova testemunhal), Penal (circunstância agravante da pena) e Previdenciário (benefícios para dependentes).

Como já visto, a isonomia constitucional entre filhos de qualquer origem impõe que, uma vez reconhecido o vínculo parental, todos os efeitos jurídicos que emanam da relação parental sejam produzidos em sua plenitude. Não existe, no direito brasileiro, uma categoria intermediária entre a parentalidade e a não-parentalidade, com regime jurídico próprio, tal como o apadrinhamento civil do direito português ou a affiliazone do direito italiano. A legislação pátria reconhece, por outro lado, direitos oriundos da relação entre padrasto ou madrasta e 
seus enteados, mas tal circunstância apenas reforça a diferença entre enteados e filhos, não servindo a equiparar as figuras, salvo se restar configurada efetivamente uma paternidade socioafetiva, hipótese que, conquanto possa se revelar de tormentosa distinção na prática, tem requisitos jurídicos próprios e gera, como resultado, a alteração do status familiar dos envolvidos, a comprovar, por isso mesmo, a distinção antes mencionada. Assim, de duas, uma: ou se trata de filho, com todos os efeitos daí decorrentes, ou não se trata de filho. ${ }^{12}$

Identifica-se na jurisprudência, todavia, certa resistência à admissão de efeitos plenos à filiação socioafetiva. Tal resistência pode ser explicada por dois fatores: primeiro, certa relutância cultural em admitir que o filho socioafetivo desfruta da mesma importância que o filho biológico na família (tal como sucedia, outrora, com os filhos ditos ilegítimos); segundo, porque a prática forense revelou, nos últimos anos, uma certa banalização do reconhecimento da socioafetividade, descuidando-se, no ímpeto de proteger a criança e o adolescente no caso concreto, de um rigor técnico na investigação dos requisitos necessários para a constituição do vínculo parental.

Conquanto se afigura compreensível, nesse cenário, a tendência de certas cortes a restringir a eficácia jurídica dos laços socioafetivos,

12 Os direitos que decorrem da relação entre o padrasto (também chamado pai afim) e seus enteados ou entre a madrasta (mãe afim) e seus enteados relacionam-se à adoção unilateral (art. 41, $\S 1^{\circ}$, da Lei $n^{\circ} 8.069 / 90$ ), à guarda (art. 1.584, $\S 5^{\circ}$, do Código Civil), a benefícios previdenciários (art. 16 , $2^{\circ}$, da Lei $n^{\circ} 8.213 / 91$ ), a licenças de servidor (arts. 83 e 97 da Lei $n^{\circ} 8.112 / 90$ ) e ao nome de família (art. $57, \S^{\circ}$, da Lei $n^{\circ} 6.015 / 73$ ), sem mencionar a possibilidade de deixar testamento. Como se vê, as figuras do enteado e do filho não se confundem e coexistem no ordenamento, com regras próprias. Nesse sentido, não cabe ao juiz estender alguns efeitos da parentalidade com a intenção de proteger o enteado, assim qualificado, como já fez o Tribunal de Justiça de Minas Gerais em caso no qual se reconheceu o direito a alimentos à enteada, sem declaração da parentalidade socioafetiva, ao fundamento de que as pessoas ligadas pelo vínculo de afinidade são parentes entre si (TJMG, AC n. 1.0024.04.533394-5/001, 4a CC, Rel. Des. Moreira Diniz, j. 20/10/2005, DJMG 25/10/2005). Da mesma forma, deve ser criticada a assertiva adotada por muitos autores, por ocasião do advento da Lei $n^{\circ} 11.429 / 09$ (Lei Clodovil), de que a alteração legal significaria um avanço no reconhecimento do fenômeno da multiparentalidade. Ainda que seja recomendável a tutela de interesses dos enteados antes ignorados pelo ordenamento jurídico, beneficiando-os com alguns direitos típicos da relação de filiação, é preciso ter em vista que a medida apenas reforça a diferença entre as figuras dos filhos e dos enteados, que, a princípio, não devem ser equiparadas. 
atribuindo-Ihes apenas alguns efeitos decorrentes da parentalidade, tal solução não se coaduna com a Constituição. Aqui, vale o dito popular: a emenda acaba sendo pior que o soneto. Cumpre ao intérprete proceder ao exame rigoroso, em concreto, dos pressupostos que ensejam a socioafetividade, evitando-se a confusão habitual que se tem promovido entre o mero sentimento de afeto e o estabelecimento de um vínculo parental, que exige mais que isso como o próprio prefixo "socio" revela. Não se deve, todavia, permitir que a eventual falta de rigor seja compensada por uma paternidade pela metade, incompatível com nossa ordem constitucional.

\section{Problemas práticos decorrentes da multiparentalidade no âmbito do Direito das Sucessões e do Direito de Família}

A seguir, serão abordados os principais problemas práticos que podem decorrer do fenômeno da multiparentalidade, notadamente em sua acepção estrita e especialmente no âmbito do Direito de Família e do Direito das Sucessões.

\subsection{Direitos sucessórios}

Inúmeras controvérsias surgem no campo sucessório, especialmente nas hipóteses de multiparentalidade superveniente, em que novo vínculo parental se forma somando-se aos já existentes. Em tais casos, questiona-se se seria legítimo uma pessoa ter direito a novas heranças, pois isso reduziria a quota hereditária dos demais sucessores, podendo traduzir uma ofensa indireta ao princípio da igualdade entre os filhos ${ }^{13}$. A situação se agrava quando o novo vínculo decorre de

13 Nessa direção, já se decidiu que "se uma pessoa pudesse, simultaneamente, ter mais de um pai ou mais de uma mãe reconhecidos como tais em seu assento de nascimento, ela receberia tratamento estatal diferenciado em relação a todos os demais cidadãos. Por conta disso, teria, por exemplo, direitos sucessórios por mais de um tronco hereditário, o que importaria, em última análise, injustificado tratamento desigual em seu favor". Tal sentença, contudo, foi reformada pelo Tribunal de Justiça de São Paulo (TJ/SP, Apelação nº 0006422-26.2011.8.26.0286, $1^{\text {a }}$ Câmara de Direito Privado, Rel. Des. Alcides Leopoldo e Silva Junior, j. 14/8/2012). 
socioafetividade e só vem a ser reconhecido post mortem ${ }^{14}$, caso em que o parente morto pode, inclusive, ter deixado testamento em favor daquela pessoa que pretende ser reconhecida como filha, confiando que não seria herdeira necessária.

Ainda que possa soar inusitado, o fato de uma pessoa ter direitos sobre heranças de diversos ascendentes em primeiro grau não encontra obstáculo na ordem constitucional vigente. Assim, independentemente da origem do vínculo, o filho será herdeiro necessário e terá direito à legítima. Ter direitos sucessórios em relação aos pais biológicos e, ao mesmo tempo, em relação aos pais socioafetivos não ofende qualquer norma jurídica, ao contrário, apenas realiza a plena igualdade entre os filhos assegurada pela Constituição. Ter um, dois, três ou até mais vínculos parentais decorre de contingências da vida, de modo que não há problema em haver irmãos legitimados a suceder em heranças distintas de seus respectivos ascendentes. Tanto é assim que não se questiona quando alguém que não tenha pai registral divide a herança da mãe com outros herdeiros que têm dois pais.

Note-se, ademais, que não é inédita, no ordenamento jurídico pátrio, a possibilidade de uma pessoa receber herança de dois pais ou de duas mães. Na adoção simples, regulada pelo Código Civil de 1916, prevalecia o entendimento de que o adotado tinha direitos sucessórios em relação ao adotante (não estendidos, em regra, aos parentes deste), sem prejuízo do direito à sucessão de seus parentes consanguíneos (PEREIRA, 2002, p. 67). Mesmo após a Constituição de 1988, já decidiu o STJ que as adoções constituídas sob a égide da codificação de 1916 "não afastam o parentesco natural, resultante da consanguinidade,

14 De acordo com a Súmula n 149 do STF, "É imprescritível a ação de investigação de paternidade, mas não o é a de petição de herança". Entende a melhor doutrina que contra o filho não reconhecido (biológico ou socioafetivo) não corre prescrição da petição de herança. Todavia, a jurisprudência majoritária no Superior Tribunal de Justiça aduz que o termo inicial do prazo prescricional de dez anos para a ação de petição de herança é a abertura da sucessão, e não o reconhecimento da parentalidade. 
estabelecendo um novo vínculo de parentesco civil tão-somente entre adotante(s) e adotado". ${ }^{15}$

Ainda sobre o tema, convém registrar que nada impede o reconhecimento do vínculo sociafetivo post mortem. ${ }^{16}$ Já na hipótese em que o filho de pai socioafetivo pretende reconhecer o laço parental com seu genitor biológico, já falecido, a legitimidade da pretensão de reconhecimento do vínculo parental tem sido criticada por doutrina de relevo:

não podem os interesses patrimoniais ser móveis de investigações de paternidade, como ocorre quando o pretendido genitor biológico falece, deixando herança considerável. Repita-se: a investigação de paternidade tem por objeto assegurar o pai a quem não tem e nunca para substituir a paternidade socioafetiva pela biológica, até porque esta só se impõe se corresponder àquela. [...] Não pode haver, conseqüentemente, sucessão hereditária entre filho de pai socioafetivo e seu genitor biológico; com relação a este não há direito de família ou de sucessões. Mas é possível resolver-se a pretensão patrimonial no âmbito do direito das obrigações. É razoável atribuir-se-lhe um crédito decorrente do dano causado pelo inadimplemento dos deveres gerais de paternidade [...] por parte do genitor biológico falecido, cuja reparação pode ser fixada pelo juiz em valor equivalente ao de uma quota hereditária se herdeiro fosse. Para isso será necessário ajuizar ação de reparação de dano moral e material [...]. (LÔBO, 2008, p. 19-20).

Parece, todavia, que o reconhecimento jurídico da multiparentalidade associado à constitucional isonomia entre filhos assegura àquele que tem o vínculo parental biológico estabelecido, ainda que na presença de outro vínculo parental de origem socioafetiva, o direito pleno à herança de ambos os pais. A sofisticada tese de que

\footnotetext{
15 BRASIL. STJ. Resp n 740.127 / SC, $3^{\text {a }}$ Turma, Rel. Min. Nancy Andrighi, j. 11/10/2005.

16 Expressamente nesse sentido, TJMG, Ap. Cível n. 1.0024.03.186.459-8/001, $4^{\mathrm{a}}$ CC, Rel. Des. Moreira Diniz, publicado em 23/03/2007.
} 
o problema se resolve por meio da reparação do dano decorrente do descumprimento de deveres parentais perde força diante da decisão do STF que vem dizer justamente o oposto: inexiste paternidade de segunda categoria ou de menor hierarquia, ou, ainda, paternidade com efeitos parciais.

Evidentemente, ações de investigação de paternidade movidas por interesse exclusivamente patrimonial, como a participação na herança, sempre existiram e continuarão a existir, haja ou não multiparentalidade. O motivo íntimo do autor, contudo, não pode servir de obstáculo à procedência do reconhecimento de uma paternidade que, de fato, existe e produz, por força de expresso comando constitucional, integral efeito. O que continua disponível ao intérprete - como também sempre esteve - são os remédios gerais de coibição do abuso do direito e do comportamento contrário à boa-fé objetiva. Hipótese emblemática se tem na situação do filho que, conhecedor por longos anos do vínculo com o pai biológico, deixa de procurá-lo e assisti-lo na velhice, sabedor de suas necessidades pessoais em virtude de doença degenerativa, mas, uma vez ocorrido o falecimento, pretende ver reconhecida aquela paternidade e se habilitar ao recebimento do seu quinhão hereditário.

O direito ao reconhecimento da paternidade biológica - com todos os seus efeitos patrimoniais ou existenciais - não assume caráter de direito absoluto, sujeitando-se, como qualquer outro, à ponderação perante outros interesses constitucionalmente tutelados, como a solidariedade social e suas manifestações, dentre as quais a proibição de comportamento contraditório ou nemo potest venire contra factum proprium (SCHREIBER, 2016). Apenas a análise de cada situação concreta permitirá verificar qual a solução adequada, mas não há razão para se afastar aí a possibilidade de incidência dos remédios gerais oferecidos pela ordem jurídica.

Reconhecida a multiplicidade de laços parentais, há, ainda, algumas questões sucessórias que precisam ser enfrentadas, como a que se refere ao quinhão dos herdeiros na hipótese em que o filho morre deixando cônjuge e três pais. Por evidente, o legislador do Código Civil 
de 2002, elaborado na década de 1970, não previu regra específica para a concorrência entre cônjuge e múltiplos ascendentes. Não obstante, aplica-se à hipótese aventada a ratio do art. 1.837 do Código ${ }^{17}$, de maneira que a solução consiste em repartir a herança em partes iguais, ficando o cônjuge, assim como os três ascendentes em primeiro grau, com um quarto cada.

Na hipótese do filho falecer deixando apenas avós de três linhas parentais, reparte-se a herança por linhas, e não por cabeça. A divisão seguirá a mens legis do art. $1.836, \S 2^{\circ}$, do Código $\mathrm{Civil}^{18}$, que, em caso de igualdade em grau e diversidade em linha, assegura metade da herança aos ascendentes da linha paterna e metade aos da linha materna. Logo, se o falecido deixa quatro avós de duas linhas paternas e apenas um avô da linha materna, a este caberá um terço da herança, ficando as avós paternas com um sexto cada.

\subsection{Direito a alimentos}

Reconhecida a multiparentalidade, um de seus corolários é o dever de alimentos. Convém recordar que, embora a experiência jurisprudencial geralmente reconheça a filiação socioafetiva como forma de proteger os filhos, também os filhos têm o dever de ampararem os pais na velhice, carência ou enfermidade (art. 229, CRFB), incluindo o dever de alimentos. Assim, pode ocorrer que um pai proponha ação de reconhecimento de paternidade socioafetiva, cumulada com alimentos, obrigando o filho socioafetivo, eventualmente, a pagar mais de uma pensão aos seus múltiplos pais. Além disso, não se deve perder de vista que, constituído um vínculo de filiação pela socioafetividade, os parentes do novo pai ou da nova mãe tornam-se parentes do filho socioafetivo até o quarto grau. Em outros termos, o filho ganha novos ascendentes e colaterais, em relação aos quais há o dever alimentar

\footnotetext{
17 "Art. 1.837. Concorrendo com ascendente em primeiro grau, ao cônjuge tocará um terço da herança; caber-lhe-á a metade desta se houver um só ascendente, ou se maior for aquele grau."

18 "Art. 1.836, $\S 2^{\circ}$ : Havendo igualdade em grau e diversidade em linha, os ascendentes da linha paterna herdam a metade, cabendo a outra aos da linha materna."
} 
genérico decorrente do parentesco, na forma dos artigos 1.696 e 1.697 do Código Civil. Dessa relação, podem advir situações delicadas, como a imposição, ao filho socioafetivo, da obrigação de prestar alimentos ao novo irmão quando inexista qualquer convívio ou afetividade entre eles.

À vista das premissas expostas até aqui, não há dúvidas de que a obrigação alimentar decorrente do poder familiar enseja o pagamento de pensão alimentícia também em favor do filho socioafetivo. Mesmo quando comprovada por exame de DNA a inexistência de filiação biológica, os tribunais têm negado pedidos de exoneração de pensão alimentícia, formulados em antecipação de tutela nas ações negatórias de paternidade, à vista da possibilidade de existência de vínculo socioafetivo ${ }^{19}$. Sendo os alimentos decorrência do princípio da solidariedade familiar, são devidos independentemente da origem do vínculo. Parte da doutrina brasileira sugere que a obrigação alimentar do parente socioafetivo é subsidiária em relação à obrigação do parente biológico (DIAS, 2007, p. 315), assertiva esta que não encontra, na tábua axiológica da Constituição, fundamento que a justifique. Há concorrência, sem qualquer ordem preferencial, da obrigação alimentar do pai registral, do pai biológico e do pai socioafetivo.

Algumas dúvidas, porém, persistem. Reconhecida, em concreto, a pluralidade de vínculos alimentares decorrente de parentalidades concomitantes, poderá o filho, em caso de necessidade, propor ação de alimentos contra qualquer dos pais não guardiões? Em caso positivo, deve ele pleitear apenas a quota correspondente àquele parente (pro rata) ou todos os pais são devedores solidários? O pai acionado poderá chamar ao processo os demais parentes devedores de alimentos? Há, na hipótese, litisconsórcio passivo necessário?

As indagações acima, embora suscitem muitas controvérsias, não constituem novidades para a doutrina e para a jurisprudência, que já há

\footnotetext{
19 Vide TJMT, Al n 52.748/2011, Quinta Câmara Cível, Rel. Des. Dirceu dos Santos, j. 14.12.2011, DJMT 16.01.2013; TJRS, AG 230679-09.2011.8.21.7000, Sétima Câmara Cível, Rel. Des. Roberto Carvalho Fraga, j. 29.06.2011, DJRS 06.07.2011; TJMG, AC n 1.0701.06.160077/001, Rel. Des. Nepomucemo Silva, j. 15.01.2009.
} 
muito enfrentam tais problemas no âmbito dos alimentos avoengos. Isso porque, na impossibilidade dos pais prestarem alimentos, são chamados a concorrer todos os avós, já que estão no mesmo grau de parentesco, respondendo de forma sucessiva e complementar à responsabilidade dos pais. No início de 2011, decidiu a $4^{\text {a }}$ Turma do Superior Tribunal de Justiça que "nos termos da mais recente jurisprudência do STJ, à luz do Novo Código Civil, há litisconsórcio necessário entre os avós paternos e maternos na ação de alimentos complementares" ${ }^{20}$. Não obstante, em julgados mais recentes, a Corte vem admitindo a propositura de ação apenas contra alguns dos avós, ${ }^{21}$ o que traz à baila as polêmicas que giram em torno da natureza solidária ou divisível da obrigação alimentar, bem como da figura do chamamento dos codevedores prevista no art. 1.698 do Código Civil.

Como se pode perceber, os problemas envolvendo os alimentos avoengos aproximam-se muito daqueles que advirão com o reconhecimento de múltiplos laços de parentalidade relativamente à obrigação alimentar dos pais. Por sua vez, as dificuldades na fixação da responsabilidade dos avôs em relação aos seus netos tendem a tornarse ainda mais recorrentes nos casos de multiparentalidade à medida que a admissão de novas linhas parentais aumentará o número de ascendentes do mesmo grau que concorrem na obrigação alimentar.

Registre-se, por fim, uma questão tormentosa na seara processual envolvendo os alimentos devidos pelo pai socioafetivo. Discute-se se o reconhecimento da parentalidade socioafetiva é uma questão prévia e incidental nas ações de alimentos. Caso o filho postule apenas pedido de alimentos em face do padrasto, pode o juiz reconhecer a obrigação alimentar decorrente do parentesco? Há pedido implícito de declaração da parentalidade socioafetiva? Pode o juiz deferir o pedido de alimentos

20 BRASIL. STJ. REsp nº 958513 / SP, $4^{a}$ Turma, Rel. Min. Aldir Passarinho Junior, j. 22/02/2011, DJe 01/03/2011.

21 BRASIL. STJ. AgRg no AREsp 138218 / MS, 3 3 Turma, Rel. Min. Massami Uyeda, j. 28/08/2012, DJe 04/09/2012; STJ. REsp nº 1211314 / SP, $3^{a}$ Turma, Rel. Min. Nancy Andrighi, j. 15/09/2011, DJe 22/09/2011; BRASIL. STJ, REsp 1415753 / MS, 3a Turma, Rel. Min. Paulo de Tarso Sanseverino, j. 24/11/2015. 
e determinar a expedição de ofício para o cartório de Registro Civil para que se inclua o novo pai socioafetivo? São indagações, que embora não digam respeito propriamente ao tema do presente estudo, por independerem de multiparentalidade, suscitam reflexão da doutrina, merecendo registro a opinião de Christiano Cassetari, para quem é dever do juiz determinar ao Registro Civil a inclusão da parentalidade socioafetiva, ainda que reconhecida incidentalmente e sem provocação da parte, não se mostrando tal decisão extra petita ou ultra petita (CASSETTARI, 2014, p. 114). Com efeito, o que não se pode ter é o reconhecimento da parentalidade socioafetiva sem a prova da presença dos requisitos necessários para tanto, mas, uma vez presentes tais requisitos, a possibilidade de seu reconhecimento não deve estar restrita pela segregação formal em ação judicial autônoma, sendo perfeitamente viável seu reconhecimento incidental, desde que assegurados ao réu o contraditório e a ampla defesa sobre tal aspecto específico.

\subsection{Exercício da autoridade parental}

A titularidade e o exercício da autoridade parental cabem a todos os pais igualmente por força da isonomia entre o homem e a mulher e da proibição de designações discriminatórias nas relações parentais, ambas consagradas na Constituição. Tal assertiva independe do arranjo familiar adotado, ainda que, portanto, multiparental.

Alude-se ao princípio da incomunicabilidade do poder familiar nos casos em que o genitor que possui a guarda do filho constitui nova família. Embora sujeito a críticas por vedar qualquer interferência do novo cônjuge ou companheiro (TEIXEIRA; RODRIGUES, 2009), o art. 1.636 do Código consagra a manutenção da autoridade parental, que não se transfere ao padrasto ou à madrasta na família recomposta. Se verificado, todavia, que o novo cônjuge ou companheiro do guardião passou a se ocupar da função parental, justamente pelo exercício fático da autoridade parental, de tal maneira que seja possível constatar um vínculo de parentesco por socioafetividade, tornar-se-á pai para todos 
os efeitos jurídicos, sujeitando-se até mesmo às hipóteses legais de perda ou suspensão do poder familiar.

As dificuldades práticas advindas do exercício simultâneo da autoridade parental por múltiplos pais devem ser solucionadas pela regra prevista no art. 1.631 do Código vigente, que prevê o suprimento judicial como solução para as divergências entre pais. Supondo um filho que tenha três laços parentais concomitantes (duas mães e um pai, por exemplo), não será suficiente a vontade da maioria deles para a representação ou assistência dos filhos menores, tampouco para a tomada de decisões relativas à emancipação voluntária, autorização para casar, administração dos bens etc. Não alcançada a unanimidade, qualquer deles poderá, a rigor, recorrer ao juiz para a superação da divergência.

Tal solução, que já não é ideal nos casos tradicionais de biparentalidade, por judicializar em excesso a vida familiar, tornase ainda mais problemática nos casos de multiparentalidade, pois a elevação do número de pais ou mães produz, inevitavelmente, uma maior possibilidade de dissenso. Aos pais, seja a situação de biparentalidade, seja a multiparentalidade, deve ser recomendado sempre o emprego prévio de mecanismos extrajudiciais de solução de conflitos, como a mediação. A judicialização do dissenso deve ser vista como última ratio, a servir de remédio em casos extremos, pela mera ausência de outra solução possível à luz do nosso ordenamento que se possa aplicar àqueles casos em que a discordância persiste.

\subsection{Impedimentos matrimoniais}

Os impedimentos matrimoniais constituem obstáculos legais a que validamente se contraia matrimônio ou se estabeleça união estável (CC, art. $1.723, \S 1^{\circ}$ ). No Código Civil de 2002, os impedimentos foram classificados em três grupos, conforme decorram: (i) do parentesco, (ii) da proibição da existência de casamento anterior ou (iii) da prática de crime. Cumpre aqui investigar se as proibições decorrentes do parentesco previstas no art. 1.521 do Código Civil se aplicam a todos 
os laços de parentalidade, independentemente de sua natureza, o que, embora não consista propriamente em problema inerente à multiparentalidade, adquire no novo contexto maior relevância. De acordo com a doutrina majoritária, a primeira hipótese prevista na lei - o casamento entre ascendentes e descendentes - é vedada por razões tanto de ordem eugênica (ou de saúde pública) como por considerações de moralidade pública. Tanto é assim que o próprio legislador afirma ser tal impedimento aplicável seja o parentesco natural, seja civil, do que se infere que pais e filhos socioafetivos não podem se casar.

A outra hipótese que poderia suscitar questionamento quanto à sua aplicabilidade às relações socioafetivas refere-se à proibição do casamento entre colaterais até o terceiro grau (entre irmãos e entre tios e sobrinhos, não consanguíneos). Embora reconheça que a ideia da repulsa ao incesto entre colaterais é um tanto relativa, afirma a doutrina que "motivos de ordem moral, e também biológica, aconselham não se unam em matrimônio parentes próximos, posto que colaterais" (PEREIRA, 2002, p. 66). No tocante ao casamento entre tios e sobrinhos socioafetivos, a própria ratio do Decreto-lei 3.200/41, à parte a polêmica sobre a sua revogação pelo Código Civil de 2002, reforça a inexistência de motivo para a sua vedação, dada a possibilidade do juiz afastar o impedimento mediante laudo médico de exame pré-nupcial de compatibilidade consanguínea.

Registre-se, por fim, que toda ideia dos impedimentos matrimoniais assenta, em larga medida, sobre o desestímulo público a casamentos intrafamiliares, que, comuns no passado, resultavam muitas vezes em riscos médicos ao filho. Moralidade e medicina fundiram-se a tal ponto na disciplina da matéria que, hoje, há certa dificuldade em identificar a função estritamente jurídica dos impedimentos matrimoniais. Nesse cenário, a solução alvitrada pelo Decreto-lei 3.200/41 ainda soa como a melhor solução para se evitar que tabus e mitos impeçam a realização de relações afetivas que se formam na vida real e que, se excluídas do âmbito matrimonial, resultarão simplesmente em uma convivência que ou será interpretada como união estável ou restará - para os autores que acatam a extensão legal dos impedimentos matrimoniais à união 
estável - marginalizada pelo Direito, mas nem por isso deixará de ocorrer e suscitar efeito jurídico ex post.

\subsection{Guarda e visitação dos filhos}

Finalmente, cumpre enfrentar o tema da guarda e da visitação dos filhos que possuem múltiplos laços parentais. Por serem vários pais, torna-se mais árdua a tarefa de definir na companhia de quem vão morar os filhos, assim como o regime de convivência por parte dos parentes não guardiões. Apesar de maior dificuldade prática em razão da maior quantidade de vínculos parentais em disputa, o critério a ser adotado será sempre o melhor interesse da criança, tal como em qualquer outra hipótese, conforme determina a doutrina da proteção integral consagrada pela Constituição (art. 227). Descabe, assim, qualquer tentativa de estabelecer critérios em abstrato e a priori, específicos para as situações de multiparentalidade - tais como a preferência da definição da guarda em favor dos pais que moram juntos em detrimento do pai que mora sozinho -, eis que poderá o magistrado se convencer do contrário, no exame do caso concreto, com vistas à proteção dos interesses do menor.

As modificações trazidas pela Lei $n^{0} 13.058 / 2014$ tornam o problema da guarda nas relações multiparentais ainda mais complexo, já que, pela letra da lei, o juiz deve fixar a guarda compartilhada quando não houver acordo entre os genitores, salvo se um deles discordar que assim o seja. Tendo em conta que a lei apenas menciona o compartilhamento da guarda entre a mãe e o pai, deve-se indagar se seria possível fixar a guarda compartilhada entre três ou mais pais. Tal possibilidade deve ser reconhecida em teoria, enfatizando-se, mais uma vez, que a resposta definitiva para o problema concreto dependerá da análise casuística - e não apriorística - pelo juiz, orientada tal análise pelo princípio do melhor interesse da criança. 


\section{Conclusão}

O reconhecimento da multiparentalidade pelo STF no âmbito da Repercussão Geral 622 representa um passo largo e decidido rumo à consagração de um Direito de Família efetivamente plural e democrático no Brasil. Na linha do que já havia feito com o reconhecimento das uniões homoafetivas, a Corte Suprema do país reitera seu papel no campo do Direito de Família: não fechar os olhos para realidade, acolhendo todas as diferentes formas de família que já existem na prática e que não se enquadram necessariamente nos modelos fechados que constam das nossas leis e dos nossos códigos. Fixada a tese da inexistência de hierarquia entre a paternidade socioafetiva e a biológica, a decisão do STF traz numerosas e profundas consequências, não apenas para o Direito de Família, mas também para outros campos jurídicos, como o Direito das Sucessões, o Direito das Obrigações, o Direito Processual, o Direito Eleitoral e o Direito Previdenciário.

A propósito, convém registrar que ao STF não compete redesenhar, em cada decisão, todo o sistema jurídico. As respostas mais específicas às repercussões que a tese possa ter em diferentes setores jurídicos virão pouco a pouco, pelas boas mãos da doutrina e da jurisprudência. Mais do que nunca, resta agora para a doutrina a incumbência do importante papel de antecipar os problemas práticos da multiparentalidade e propor parâmetros que possam balizar o intérprete - em especial, os juízes das Varas de Família - na harmonização dos interesses que poderão entrar em rota de colisão nas famílias multiparentais.

Nesse esforço, é inevitável reconhecer que as alterações axiológicas introduzidas pela Constituição na disciplina familiar vedam qualquer tratamento diferenciado aos filhos, independentemente da natureza do laço parental. Logo, uma vez reconhecido o vínculo, restarão presentes todos os efeitos jurídicos decorrentes da relação estabelecida entre pais e filhos, independentemente da origem do parentesco. Há, nesse sentido, plena igualdade entre a parentalidade biológica, jurídica e socioafetiva, de tal modo que o reconhecimento do vínculo, de 
origem "natural" ou civil atrairá todos os efeitos jurídicos decorrentes do parentesco no complexo de relações que constitui o fenômeno familiar.

A análise dos efeitos jurídicos da multiparentalidade, aqui examinada especialmente em sua concepção estrita, que compreende apenas o reconhecimento jurídico de mais de dois vínculos parentais à mesma pessoa, revelou a existência de problemas práticos que podem ser divididos em dois grupos: (i) aqueles que surgem do próprio reconhecimento do fenômeno multiparental (e.g., o problema da sucessão dos ascendentes múltiplos em caso de falecimento do filho anteriormente ao falecimento dos pais), e (ii) aqueles que já são existentes hoje em dia, mas se agravam ou se sobressaem quando reconhecidos plúrimos laços parentais (e.g, alimentos múltiplos e guarda compartilhada). Em todos os casos, a solução dos problemas há de ser buscada sempre na tábua axiológica consagrada na Constituição, por meio da aplicação direta dos princípios constitucionais.

Os problemas não são tão difíceis de solucionar nem tão novos quanto se poderia imaginar em uma suposição precipitada, fortemente influenciada pela natural perplexidade que nos provoca a quebra de um paradigma tão consolidado em nossa cultura - o da sacralidade da família nuclear, constituída pelo pai, pela mãe e pelos filhos. O exame dos efeitos jurídicos da multiparentalidade demonstrou que, ao contrário do que o senso comum costuma apontar, não há dificuldades práticas nas famílias multiparentais que não possam ser solucionadas pelos aplicadores do direito, à luz dos valores constitucionais, a partir das ferramentas hoje disponíveis e com base nas construções já efetuadas em outras searas pela doutrina e pela jurisprudência brasileiras.

\section{Referências}

ALBUQUERQUE, Fabíola Santos. Poder familiar nas famílias recompostas e o art. 1.636 do CC/2002. In: PEREIRA, Rodrigo da Cunha (Coord.). Afeto, ética, família e o novo Código Civil brasileiro. Anais do IV Congresso Brasileiro de Direito de Família. Belo Horizonte: Del Rey, 2004. p. 161-179. 
BARBOZA, Heloisa Helena. Efeitos jurídicos do parentesco socioafetivo. Revista Brasileira de Direito das Famílias e Sucessões, Porto Alegre, v. 11, n. 9, p. 25-34, 2009.

BEZERRA, Elton. Pai biológico x socioafetivo: caso H. Stern expõe conflito de jurisprudências. Revista Consultor Jurídico, São Paulo, 19 set. 2012. Disponível em: <http://www.conjur.com.br/2012-set-19/ disputa-heranca-stern-expoe-conflito-jurisprudencias>. Acesso em: 26 ago. 2016.

CASSETTARI, Christiano. Multiparentalidade e parentalidade socioafetiva: efeitos jurídicos. São Paulo: Atlas, 2014.

CALDERÓN, Ricardo. Reflexos da decisão do STF de acolher socioafetividade e multiparentalidade. Revista Consultor Jurídico, São Paulo, 25 set. 2016. Disponível em: <http://www.conjur.com. br/2016-set-25/processo-familiar-reflexos-decisao-stf-acolhersocioafetividade-multiparentalidade>. Acesso em: 15 ago. 2016.

CATALAN, Marcos. Um ensaio sobre a multiparentalidade: explorando no ontem pegadas que levarão ao amanhã. Revista da Faculdade de Direito - UFPR, Paraná, n. 55, p. 143-163, 2012.

DIAS, Maria Berenice. Manual de direito das famílias. 4. ed. São Paulo: Revista dos Tribunais, 2007.

FACHIN, Luiz Edson. Estabelecimento da filiação e paternidade presumida. Porto Alegre: Sergio Antonio Fabris, 1992.

LÔBO, Paulo Luiz Netto. Entidades familiares constitucionalizadas: para além do numerus clausus. Jus Navigandi, Teresina, ano 6, n. 53, jan. 2002. Disponível em: www.jus.com.br>. Acesso em: 17 jul. 2016.

LÔBO, Paulo Luiz Netto. Socioafetividade no Direito de Família: a persistente trajetória de um conceito fundamental. Revista Brasileira de Direito das Famílias e Sucessões, Porto Alegre, v. 10, n. 5, p. 5-22, 2008.

MADALENO, Rolf Hanssen. Paternidade alimentar. Revista Brasileira de Direito de Família, Porto Alegre, n. 37, p. 133-164, 2006. 
MATOS, Ana Carla Harmatiuk. Aspectos jurídicos da homoparentalidade. In: PEREIRA, Rodrigo da Cunha (Org.). Família e responsabilidade: teoria e prática do direito de família. Porto Alegre: Magister / IBDFAM, 2010. p. 39-48.

PEREIRA, Caio Mario da Silva. Instituições de direito civil. 13. ed. Rio de Janeiro: Forense, 2002.

SCHREIBER, Anderson. A proibição de comportamento contraditório: tutela da confiança e venire contra factum proprium, São Paulo: GEN, 2016. v. 5.

SCHREIBER, Anderson. O Direito cai na real. O Globo. 2016. Disponível em: <http://oglobo.globo.com/opiniao/o-direito-cai-nareal-20243167>. Acesso em: 6 out. 2016.

SCHREIBER, Anderson. STF, Repercussão Geral 622: a Multiparentalidade e seus Efeitos. Carta Forense. 2016. Disponível em: <http://www.cartaforense.com.br/conteudo/artigos/stf-repercussaogeral-622-a-multiparentalidade-e-seus-efeitos/16982>. Acesso em: 26 set. 2016.

TARTUCE, Flavio. O princípio da afetividade no Direito de Família: breves considerações. Disponível em: < http://www.flaviotartuce.adv.br/ artigos/3>. Acesso em: 15 out. 2016.

TEIXEIRA, Ana Carolina Brochado; RODRIGUES, Renata Lima. Multiparentalidade como efeito da socioafetividade nas famílias recompostas. Revista Brasileira de Direito das Famílias e Sucessões, Porto Alegre, v. 11, n. 10, p. 34-60, 2009.

TEPEDINO, Gustavo. A disciplina da guarda e a autoridade parental na ordem civil-constitucional. Revista Trimestral de Direito Civil RTDC, Rio de Janeiro, ano 5, v. 17, p. 33-49, jan./mar. 2004.

TEPEDINO, Gustavo. Temas de Direito Civil. 4. ed. Rio de Janeiro: Renovar, 2008.

VILELA, João Batista. Desbiologização da paternidade. Revista da Faculdade de Direito da Universidade Federal de Minas Gerais, 
Belo Horizonte, v. 27, n. 21, p. 400-418, 1979. Disponível em:<http:// www.direito.ufmg.br/revista/index.php/revista/article/view/1156/1089>. Acesso em: 16 out. 2014.

Recebido em: $17 / 10 / 2016$

Aprovado em: 30/11/2016 